\title{
PENGEMBANGAN QUANTUM TEACHING BERBASIS VIDEO PEMBELAJARAN CAMTASIA PADA MATERI PERMUKAAN BUMI DAN CUACA
}

\author{
Dewi Ayu Sulistyaningrum \\ Fakultas Ilmu Pendidikan, Universitas PGRI Semarang \\ email: dewiayusulistya@gmail.com
}

\begin{abstract}
The Research to motivate students learning and helping teacher to give theory by Quantum Teaching Development model by using audio visual media software based on camtasia studio 8, as a valid and practical learning media. The type of Research Used is Research and Development. The procedure in this development study apply the according to Borg and Gall with initial research and information collection, planning, product draft development, initial field trials, revision test of the results. The result of media validation at first stage media expert was 57,5\% and stage 2 was 91,25\%, second media expert validation was 95\%, material validation result in first material expert of phase 1 was 55,71, and phase 2 was 95, 71\%, second material expert validation 95,71\%, student response question 93,75\%. Then camtasia based on audio visual media with quantum teaching media is valid and ready for field trial. Then the questionnaire responses of students as much as $92.68 \%$ and questionnaire teacher response learning media and learning materials $97 \%$ and $100 \%$. So it can be concluded that the development of quantum teaching based on camtasia learning video is valid and practical so that motivated learning besides feasible use learning in Elementary School.
\end{abstract}

Keywords: Quantum Teaching, Camtasia

\section{PENDAHULUAN}

Pendidikan ialah usaha sadar dan terencana manusia untuk mencapai tujuan yang diinginkan dan pendidikan dapat membina kepribadiannya seseorang sesuai dengan nilai-nilai di dalam masyarakat dan kebudayaan. Pendidikan tidak dapat muncul secara kebetulan saja. Usaha sadar untuk memenuhi kebutuhan terdidik bukan untuk memenuhi kebutuhan pendidik. Pendidikan diartikan sebagai usaha yang dijalankan oleh seseorang atau mencapai tingkat hidup atau penghidupan yang lebih tinggi dalam mental.

Demikian proses pembelajaran tercapai atau tidaknya pembelajaran tergantung pada dilihat dari hasil proses pembelajaran tersebut. Proses belajar itu terjadi karena adanya interaksi antara seseorang dengan lingkungannya. Pendidikan sangatlah mempengaruhi dalam proses pembelajaran karena menyangkut kegiatan pembelajaran guru sebagai pengajar harus dituntut mempunyai kualitas mengajar yang baik agar peserta didik dapat secara terencana, baik dalam aspek pengetahun, keterampilan, maupun sikap. Interaksi yang terjadi selama proses belajar tersebut dipengaruhi oleh lingkungan.

Berdasakan analisis wawancara yang dilakukan oleh peneliti di SDN Jomblang 01 Semarang di dapatkan fakta bahwa banyak peserta didik yang menyukai pelajaran IPA, namun ada menganggap sukar karena jarang menggunakan media dalam pembelajaran karena keterbatasan guru dalam membuat media pembelajaran saat pembelajaran 
berlangsung atau keterbatasan koleksi media di sekolah, akan tetapi mereka sangat berharap agar pembelajaran IPA di sekolah dapat di laksanakan secara efisien, menarik, dan efektif. Kemudian dari wawancara juga dapat diketahui bahwa terdapat saranaprasarana berkaitan dengan teknologi yang kurang dimanfaatkan oleh guru. Metode pengajaran menggunakan metode ceramah dan menggunakan media gambar tetapi media gambar tersebut juga tidak terlalu sesering mungkin, lebih banyak menggunakan metode ceramah dan sumber belajar yang biasanya menggunakan buku pegangan yaitu BSE dan buku KTSP, guru lebih sering sebagai teacher centered dalam proses pembelajaran berlangsung di dalam kelas maka dari itu siswa kurang aktif dalam pembelajaran berlangsung.

Berdasarkan hasil wawancara dan observasi dengan narasumber guru kelas III di Sekolah Dasar Negeri Jomblang 01 kelas masih menggunakan kurikulum KTSP pada mata pelajaran IPA memiliki KKM yang tinggi yaitu sebesar 67. Suatu kegiatan belajar mengajar dikatakan berhasil apabila lebih dari $80 \%$ siswa lolos KKM dari 41 siswa kelas III SDN Jomblang 01 berdasarkan nilai IPA pada Ulangan Tengah Semester ganjil. Berdasarkan KKM yang tinggi tersebut dapat memacu guru untuk membuat suatu proses belajar mengajar yang dapat memotivasi siswa untuk terus belajar dan memiliki hasil yang baik, Namun faktanya, guru kelas III lebih sering menggunakan buku sebagai media pembelajaran dan menggunakan metode ceramah.

Pembelajaran Quantum adalah salah satu model pembelajaran yang inovatif yang berorientasi pada peserta didik (student centered). Pembelajaran Quantum difokuskan pada hubungan yang dinamis dalam lingkungan kelas dengan interaksi membentuk landasan dan kerangka untuk belajar. Model pembelajara Quantum menekankan kegiatan pada pengembangkan potensi manusia secara optimal melalui caracara yang sangat manusiawi, yaitu mudah, menyenangkan, dan memberdayakan. Setiap anggota komunitas belajar dikondisikan untuk saling mempercayai dan saling mendukung. Peserta didik dan guru berlatih dan bekerja sebagai tim guna mencapai kesuksesan bersama. Dalam konteks ini, sukses guru adalah sukses peserta didik, dan sukses peserta didik berarti sukses guru. (Kosasih \& Sumarna, 2013:89). Model pembelajaran Quantum Teaching ini efektif meningkatkan karakter kreatifitas dan hasil belajar Matematika pada siswa kelas III SD Negeri Peterongan (Permana dkk, 2016: 154)

Pengembangan potensi diri siswa akan berjalan dengan efektif apabila seorang mampu menggunakan model dan media mengajar yang tepat. Penerapan model dan media pembelajaran yang akan dipilih oleh guru dalam memberikan suatu materi pembelajaran akan diajarkan sangat menentukan terhadap keberhasilan proses belajar peserta didik, terutama yang harus diperhatikan guru adalah pemilihan dan penggunaan model pembelajaran serta media pembelajaran yang cocok pada materi pembelajaran yang akan diajarkan. Penggunaan media pembelajaran pada pembelajaran di sekolah dasar menjadi bagian paling penting yang harus diperhatikan oleh guru sebab siswa sekolah 
dasar memilki kemampuan yang terbatas dalam memahami materi bersifat abstrak.

Media audio-visual adalah seperangkat alat yang dapat memproyeksikan gambar bergerak dan bersuara. Paduan antara gambar dan suara membentuk karakter sama dengan objek aslinya. Alat-alat yang termasuk dalam kategori media audio-visual, adalah: televisi, video-VCD, sound, slide, dan film. (Sanaky 2013: 119).

Berdasarkan paparan diatas pengertian media berbasis audio visual dapat disimpulkan bahwa seperangkat alat media yang dapat bergerak dan bersuara dalam memproyeksikan dari gambar yang menarik dan bagi yang melihat dapat tertarik.

Audio visual akan dikembangkan melalui dengan software camtasia 8 dan dipadukan dengan power point 2010, Camtasia Studio adalah salah satu yang dapat merekam segala sesuatu yang sedang berlangsung dalam layar monitor anda (Enterprise 2015: 1),. Sedangkan menurut Adi (2014: 1), “Camtasia Studio merupakan salah satu software multimedia yang sering digunakan untuk membuat video, baik berupa untuk editing film ataupun video tutorial.

Menggunakan software camtasia 8, kemampuan utama camtasia adalah merekam aktivitas layar deskop secara punuh atau sebagia, dan menyimpan hasil rekaman ke dalam format video. kelebihan lain ialah camtasia adalah mampu merekam melalui kamera komputer atau webcam. Untuk mengedit video, camtasia memiliki menu yang lengkap sehingga software ini cukup mudah digunakan untuk seorang pemula sekalipun. Pengguna Camtasia akan sangat leluasa dalam mengedit konten film yang akan dibuat, karena Camtasia mampu digunakan untuk impor video, gambar (foto), musik, dan lain-lain. Selaian itu camtasia studio 8 merupakan salah satu perangkat lunak atau software yang dapar digunakan untuk pembuatan video atau untuk mengedit video software ini juga baik untuk pemula.

Berdasarkan pokok pikiran di atas menjadi acuan untuk mengembangkan model pembelajaran dan media pembalajaran untuk dapat menciptakan suasana pada saat proses pembelajaran berlangsung diharapkan setelah menggunakan pengembangan model pembelajaran quantum teaching berbasis video camtasia untuk membantu guru dalam proses kegaiatan belajar mengajar, maka peneliti mengembangkan model pembelajaran kreatif dan inovatif berbasis video camtasia.

Belajar ialah suatu proses usaha yang dilakukan seseorang untuk memperoleh suatu perubahan tingkah laku yang baru secara keseluruhan, sebagai hasil pengalamannya sendiri dalam interaksi dengan lingkungannya.(Slameto 2010: 3)

Berdasarkan pengertian di atas dapat disimpulkan bahwa belajar adalah usaha sadar yang dilakukan oleh seseorang dengan sengaja memperoleh konsep yang dinginkan sehingga seseorang dapat kemungkinan seseorang terjadi tingkah laku dan pola berpikir.

Sains atau IPA adalah usaha manusia dalam memahami alam semesta melalui pengamatan yang tepat pada sasaran, serta menggunakan prosedur, dan dijelaskan dengan penalaran sehingga mendapatkan suatu kesimpulan (Susanto 2016: 167). 
Berdasarkan menurut para ahli pembelajara IPA ialah suatu kumpulan pengetahuan yang sistematik yang di dalamnya membahas tentang gejala-gejala alam dan lingkungan sekitar alam maka dari itu IPA dalam melalui pengamatan, prosedur, penalaran yang logis maka dapat disimpulkan dalam memahami alam semesta ini

DePorter dkk (1999: 4) dalam (Sukardi, 2013: 81) Secara umum Quantum Teaching adalah sebuah metode dan proses pembelajaran di dalam kelas yang mengoptimalkan interaksi berbagai unsur yang ada pada siswa dan lingkungan belajar. Dalam interaksi ini berbagai unsur belajar efektif dilibatkan (antusiasime dan semangat belajar siswa). Hasil interaksi ini diharapkan dapat mengubah dan melejitkan kemampuan dan bakat siswa. Kemampuan dan bakat ini pada akhirnya akan menjadi presentasi dan hasil belajar yang bermanfaat bagi mereka sendiri dan orang lain. Jadi berbagai unsur yang diinteraksikan ibarat sebagai energi, dan kompetensi siswa yang meningkat pesat disimbolkan sebagai cahaya yang dihasilkan dari interaksi tersebut.

Menurut De Potter (1999) dalam (Sukardi, 2013: 93) Metode AMBAK adalah akronim dari APA MANFAAT BAGIKU. Ini adalah metode untuk mendorong siswa memahami dan menyadari bahwa apa yang mereka pelajari akan memberikan manfaat yang besar bagi dirinnya maupun orang lain. Metode TANDUR adalah metode umum dalam kegiatan inti pembelajaran. TANDUR adalah akronim dari Tumbuhkan, Alami, Namai, Demonstrasikan, Ulangi dan Rayakan.

Media pembelajaran adalah sarana atau alat bantu pendidikan yang dapat digunakan sebagai perantara dalam proses pembelajaran untuk mempertinggi efektifitas dan efisien dalam mencapai tujuan pengajaran. (Sanaky, 2013: 3)

Media visual yang menggabungkan penggunaan suara memperlukan pekerjaan tambahan untuk memproduksinya. Salah satu pekerjaan penting yang diperlukan dalam media diperlukan dalam media audio-visual adalah penulisan naskah dan storyboard yang memerlukan persiapan yang banyak, rancangan, dan penelitian (Arsyad, 2015: 91)

Kemampuan utama camtasia adalah merekam aktivitas layar desktop secara penuh atau sebagian dan menyimpan hasil rekaman ke dalam format video. Kemampuan lain camtasia adalah mampu merekam melalui kamera komputer atau webcam. Untuk mengedit video, camtasia memiliki menu yang lengkap sehingga software ini cukup mudah digunakan untuk seorang pemula sekalipun. Pengguna Camtasia akan sangat leluasa dalam mengedit konten film yang akan dibuat, karena Camtasia mampu digunakan untuk impor video, gambar (foto), musik, dan lainlain.

Hasil penelitian relevan yang dilakukan oleh Anik Wijayanti (2016) yang berjudul Pengaruh Quantum Teaching dalam Pembelajaran IPA terhadap Hasil Belajar Siswa Kelas III SD SE-GUGUS 2 Hasanudin, menunjukkan perbedaan hasil belajar antara kelompok siswa yang mengikuti pembelajaran menggunakan quantum teaching dan kelompok siswa yang mengikuti pembelajaran yang biasa dilakukan guru dibuktikan dari hasil t-test pada taraf signifikansi $0,00<0,05$. 
Berdasarkan Hasil penelitian Anik Wijayanti (2016) dengan judul Pengaruh Quantum Teaching dalam Pembelajaran IPA terhadap Hasil Belajar Siswa Kelas III SD SE-GUGUS 2 Hasanudin, menunjukkan perbedaan hasil belajar IPA yang signifikan antara kelompok siswa yang mengikuti pembelajaran dengan model pembelajaran quantum teaching dengan kelompok siswa yang mengikuti pembelajaran dengan konvensional. Hal ini sesuai dengan hasil penelitian yang dilakukan oleh peneliti bahwa lebih berpengaruh pada valid dan efektitifnya implementasi pembelajaran dengan model pembelajaran quantum teaching.

\section{METODE PENELITIAN}

Prosedur dalam

penelitian pengembangan yaitu dengan pemikiran dikemukakan oleh Borg and Gall model ini memiliki 10 langkah prosedur penelitian dan pengembangan. Namun pada peneliti dan pengembangan hanya menggunakan sampai langkah ke lima dikarenakan keterbatasan waktu dan biaya, peneliti hanya menggunakan sampai dengan tahap ke lima sebagai berikut : 1) Penelitian dan pengumpulan data, 2) Perencanaan, 3) pengembangan draf produk, 4) Uji coba lapangan awal, 5) Merevisi hasil uji coba.

Pada tahap ini peneliti melakukan observasi ditiga sekolah, di SDN Pandean Lamper 03 Semarang yang dilakukan pada tanggal 31 Januari 2017, SDN Sambirejo 02 Semarang yang dilakukan pada tanggal 1 Februari 2017 dan SDN Jomblang 01 Semarang yang dilakukan pada tanggal 2 Februari 2017, untuk menganalisis kebutuhan guru dan siswa terdahap model pembelajaran dan media pembelajaran. Dari hasil observasi yang dilakukanoleh peneliti, pada tiap-tiap sekolah terdapat permasalahan yang munculnya yaitu saat proses pembelajaran berlangsung terutama dalam pembelajaran IPA siswa perlu adanya media pembelajaran yang menarik agar dapat mengingat materi yang diajarakan dan bisa membuat siswa merasakan minat belajar untuk menerima pembelajaran atau materi yang baru karena perlunya adanya media pembelajaran. Keterbatasan guru dalam membuat media pembelajaran yang bervariasi dengan model pembelajaran, serta besarnya ketertarikan guru dalam menggunakan model pembelajaran quantum teaching berbasis video pembelajaran camtasia pada pembelajaran IPA.

Berdasarkan permasalahan tersebut perlu adanya pengembangan model pembelajaran quantum teaching berbasis video pembelajaran camtasia pada materi permukaan bumi dan cuaca. Pada produk yang dikembangkan oleh peneliti, membuat sepraktis mungkin agar dapat digunakan penelitian dan pengembangan di sekolah dan dapat meningkatkan minat belajar siswa.

Subyek penelitian pada penelitian ini adalah siswa kelas III SD Negeri Jomblang 01 dengan jumlah 41 peserta didik. Waktu penelitian adalah semester genap tahun ajaran 2016/2017. Penelitian berdasarkan dari hasil studi pendahuluan yang dilakukan oleh peneliti.

Beberapa pengumpulan data menggunakan instrumen yang dibutuhkan untuk mengetahui masalah-masalah yang ada dalam subyek penelitian harapannya peneliti 
dapat mendesain produk sesuai dengan tujuan penelitian. Berikut ini dibahas beberapa instrumen pengumpulan data yang dilakukan dalam penelitian ini :

1. Observasi

Teknik pengumpulan data dengan observasi digunakan untuk mengambil data dari sekolah yang akan diteliti. Pada penelitian ini melakukan obsevasi di tiga sekolah yaitu SDN Pandean Lamper 03 Semarang, SDN Sambirejo 02 Semarang dan SDN Jomblang 01 Semarang untuk mengumpulkan data atau mendapatkan informasi dari sekolah yang berkaitan tentang proses pembelajaran di kelas III yang berkaitan tentang model pembelajaran yang digunakan oleh guru dan media pembelajaran yang sering guru gunakan khususnya pada mata pelajaran IPA yang berlangsung di sekolah

2. Pengamatan Langsung

Dalam banyak kasus, pengamatan tingkah-laku langsung sistematis merupakan metode pengukuran paling diinginkan. Peneliti mengidentifikasi tingkah-laku yang menarik dan merancang prosedur yang sistematis untuk mengidentifikasi, mengkategorikan dan mencatat tingkah laku dalam situasi alamiah atau pertunjukan (Soegeng, 2016: 132). Pengamatan langsung dalam penelitian ini akan dilakukan saat kegiatan belajar mengajar dilaksanakan.

3. Wawancara

Wawancara pada penelitian ini dilakukan secara tidak terstruktur.

4. Dokumentasi

Dokumentasi merupakan teknik pengumpulan data yang berupa bendabenda tertulis seperti buku-buku, majalah, dokumen, peraturan-peraturan, foto-foto, dan lain sebagainya. Dalam penelitian ini, yang dimaksud adalah data responden dalam penelitian ini. Dokumentasi dari penelitian ini adalah berupa foto dan dokumen lain yang menunjang dalam penelitian ini.

5. Angket atau kuesioner

Angket atau kuesioner adalah jumlah pertanyaan tertulis yang digunakan untuk memperoleh informasi dari responden dalam arti laporan tentang pribadinya, atau hal-hal yang ia ketahui. (Arikunto , 2010: 194)

Teknik angket ini digunakan untuk menganalisis kebutuhan peserta didik dalam mengetahui proses pembelajaran mengunakan video camtasia dan analisis kebutuhan guru dalam melaksanakan proses pembelajaran berlangsung, salain itu teknik angket digunakan untuk mengetahui dalam uji validitas dalam proses pengembangan quantum teaching berbasis video camtasia agar dapat dikatan layak sebagai pembelajaran di sekolah dasar

Kuesioner diberikan kepada angket tanggapan siswa, angket respon guru dan angket validasi produk kepada para ahli media dan ahli materi yaitu sebagai berikut:

a. Lembar angket peserta didik

Data kuantitatif skor penilaian yang diperoleh dari hasil pengisian lembar angket peserta didik kemudian dianalisis dengan acuan yang diadaptasi dengan menggunakan skala Guttman yang nantinya akan dideskripsikan secara kualitatif. Angket ini digunakan untuk mengetahui kelayakan penggunaan 
quantum teaching berbasis video camtasia pembelajaran yang dikembangkan. Lembar angket peserta didik diberikan kepada peserta didik setelah mereka menggunakan atau mengikuti pembelajaran dengan menggunakan media tersebut. Lembar angket peserta didik berbentuk checklist

b. Lembar validasi

Lembar validasi digunakan untuk mendapatkan validasi dari ahli tentang kualitas quantum teaching berbasis video camtasia. Lembar validasi ini berbentuk checklist. Kualitas dalam video tersebut dijabarkan kedalam indikatorindikator dan dikembangkan lebih lanjut. Lembar validitas ini terdiri dari dua macam yaitu lembar validitas ahli media dan lembar validitas ahli materi pembelajaran

c. Lembar angket kelayakan

Data kuantitatif skor penilaian yang diperoleh dari hasil pengisian lembar angket kelayakan yang diisi oleh guru akan dianalisis dengan acuan yang diadaptasi menggunakan skala Likert yang nantinya akan dideskripsikan secara kualitatif. Angket ini digunakan untuk mengetahui kelayakan penggunaan quantum teaching berbasis video camtasia pembelajaran yang dikembangkan. Angket kelayakan ini diberikan kepada guru setelah menggunakan model pembelajaran quantum teaching berbasis video camtasia tersebut. Untuk menganalisis data dari lembar angket dengan skala Likert bentuk chekclist.

Penelitian dan pengembangan ini digunakan dua teknik analisis data yaitu deskriptif kualitatif dan analisis deskriptif kuantitatif. Data kuantitatif berupa komentar dan saran perbaikan produk dari ahli media pembelajaran dan ahli materi pembelajaran yang nantinya akan dideskripsikan secara deskriptif kualitatif untuk perbaikan produk yang dikembangkan. Sedangkan data kuantitatif berupa skor penilaian ahli media pembelajaran dan ahli meteri pembelajaran

Insrumen angket menggunakan skala Likert. Skala Likert digunakan pada angket pengujian pengembangan quantum teachingberbasis video pembelajaran camtaisa untuk uji validasi ahli media, uji ahli ahli materi, uji respon guru kelas, dan uji angket respon siswa

Penelitian dengan menggunakan skala Likert yaitu dengan menghadirkan sejumlah pernyataan yang positif dan negatif dalam suatu obyek. Dalam menjawab butir-butir pertanyaan dan dapat dipilih jawaban yang meliputi "5(sangat baik)", "4 (baik)", "3 (cukup)", "2 (kurang)" dan "1 (sangat kurang)". Juga menggunakan skala Guttman hanya memiliki dua interval saja, yaitu "setuju" dan "tidak setuju".

Data yang telah terkumpul kemudian dianalisis dengan cara menghitung skor yang diperoleh. Analisis skor yang digunakan yaitu analisis deskriptif yang digunakan untuk menghitung persentase dari hasil angket yang akan diberikan untuk ahli media, ahli materi, angket respon guru kelas dan 
angket tanggapan siswa dengan langkahlangkah sebagai berikut:

1. Data yang diperoleh dari ahli media, ahli materi memiliki validitas isi berupa data kualitatif yang diubah menjadi data kuantitatif dengan ketentuan pedoman pemberian skor seperti pada tabel 1,2 , dan 3:

Tabel. 1

Pedoman Pemberian Skor Ahli Media, Ahli Materi Angket dan Respon Guru

\begin{tabular}{|l|c|}
\hline Keterangan & Skor \\
\hline SB (Sangat Baik) & 5 \\
\hline B (Baik) & 4 \\
\hline C (Cukup) & 3 \\
\hline K (Kurang) & 2 \\
\hline SK (Sangat Kurang ) & 1 \\
\hline
\end{tabular}

Tabel. 2

Pedoman Penskoran Angket Respon Siswa

\begin{tabular}{|c|c|}
\hline Keterangan & Skor \\
\hline Tidak & 0 \\
\hline Ya & 1 \\
\hline
\end{tabular}

2. Setelah data terkumpul, kemudian menghitung skor yang diperoleh dari hasil angket yang telah diisi.

3. Menjumlahkan skor ideal item (kriterium) untuk seluruh aspek pada angket yang telah diisi

4. Menghitung persentase angka dari analisis data yang dilakukan.

5. Dari yang telah diperoleh kemudian ditransformasikan ke dalam kalimat yang bersifat kualitatif.

6. Untuk menentukan kriteria kelayakan dilakukan dengan cara seperti Tabel 3.
Tabel. 3. Kriteria Interprestasi Kelayakan Media

\begin{tabular}{|l|l|}
\hline \multicolumn{1}{|c|}{ Penilaian } & \multicolumn{1}{c|}{ Kategori } \\
\hline $0 \%-20 \%$ & Sangat tidak layak \\
$21 \%-40 \%$ & Tidak layak \\
$41 \%-60 \%$ & Cukup Layak \\
$61 \%-80 \%$ & Layak \\
$81 \%-100 \%$ & Sangat Layak \\
\hline
\end{tabular}

\section{HASIL DAN PEMBAHASAN}

Pengembangan model quantum teaching terhadap video pembelajaran berbasis camtasia pada materi permukaan bumi dan cuaca dalam materi IPA kelas III semester II, dikembangkan berdasarkan langkah-langkah penelitian dan pengembangan (Research and Development). Penelitian menggunakan desain pengembangannya yang dikemukakan oleh Borg and Gall. Pada media video pembelajaran yang akan membantu siswa dalam memahami mata pelajaran IPA terutaman materi permukaan bumi dan cuaca kelas III semester II dan membantu guru untuk menyampaikan pembelajaran di kelas.

Keunggulan produk model quantum teaaching terhadap video pembelajaran camtasia pada sifatnya mampu dibawah kemanapun, dengan tampilan menarik dan disertai animasi yang menarik dan disertai gambar-gambar yang kongkret yang disekitar lingkungan siswa yang sering siswa melihat, selain itu video pembelajaran ini siswa dapat belajar mandiri dan didampingi oleh wali murid siswa di dalam video pembelajaran ini terdapat percobaan yang siswa dapat mencoba di rumah mereka. Model quantum teaching terhadap video pembelajaran berbasis camtasia dikemas semenarik mungkin dalam bentuk CD pembelajaran. Kelayakan media ini dapat diliihat dari hasil 
validasi ahli media, validasi ahli materi, hasil angket respon guru dan hasil angket respon siswa.

\section{Hasil Validasi Ahli Media}

Pada tahap validasi ahli media ini bertujuan untuk mengetahui kelayakan pembuatan produk model quantum teaching terhadap video pembelajaran berbasis camtasia pada materi permukaan bumi dan cuaca sebelum dilakukan uji coba lapangan awal. Pada tahap ini dua validator ahli media dipilih oleh peneliti. Validasi media dilakukan dengan memberikan lembar angket validasi ahli media.Berdasarkan hasil validasi yang dilakukan oleh peneliti terdahap validator ahli media validasi pertama.

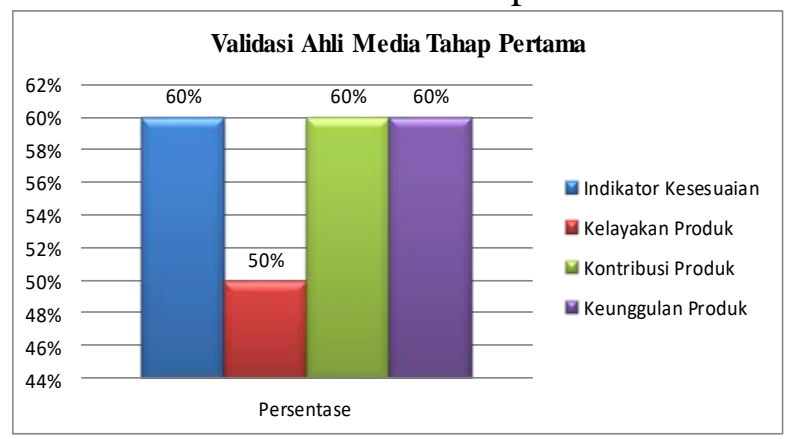

Gambar 1. Hasil Validator Media Tahap Pertama

Hasil analisis penilaian ahli media pada tahap pertama mendapatkan persentase memperoleh skor $57,7 \%$ dengan kriteriaCukup Layak dan ahli media memberikan saran dan komentar yang diberikan yaitu video pembelajaran berbasis camtasia menyesuaikan dengan model quantum teaching yang menggunakan sintaks metode TANDUR karena dalam video pembelajaran tersebut belum ada sintaks metode TANDUR, maka dari itu peneliti perlu adanya revisi produk yang sesuai dengan saran dan komentaryang diberikan oleh validasi ahli media pada tahap pertama. Setelah selesai melakukan validator pada ahli media pertama, peneliti melakukan validator ahli media yang kedua.

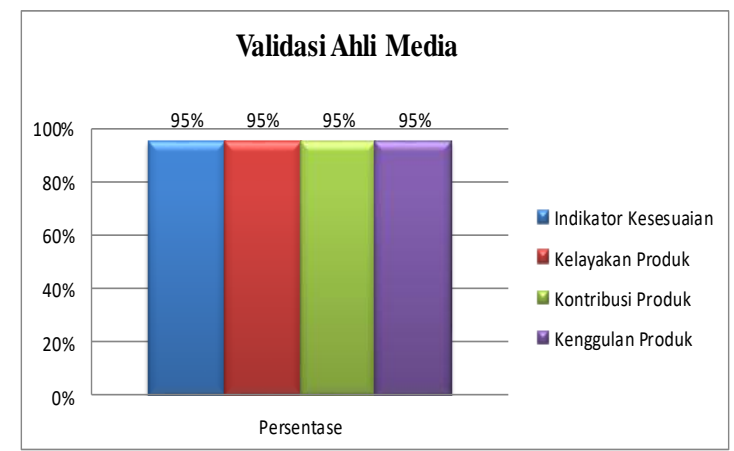

Gambar. 2 Hasil Validator Media Kedua

Hasil analisis penilaian hasil media validasi kedua mendapatkan persentase total sebesar 95\% dengan kriteria Sangat Layak dan ahli media pada validator kedua memberikan komentar yaitu siap untuk digunakan untuk penelitian atau siap untuk uji coba lapangan awal.

Pada validator yang pertama mendapatkan saran, kritikan dan komentar untuk revisi produk maka peneliti memperbaiki desain yang sesuai dengan komentar validator ahli media dan diperoleh hasil analisis penilaian ahli media validasi media pada tahap kedua

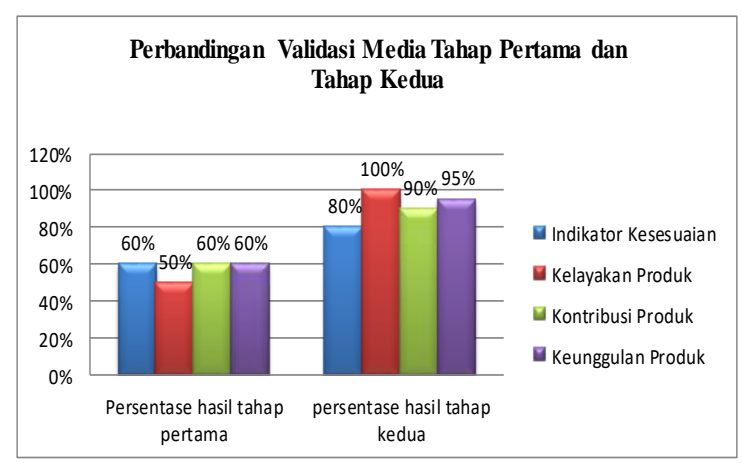

Gambar. 3 Hasil Perbandingan Validasi Media 
Hasil analisis penilaian ahli media validasi pada tahap kedua mendapatkan persentase skor total sebesar 91,25\% dengan kriteria Sangat Layak. Maka produk yang sudah validasi siap untuk uji coba lapangan.

\section{Hasil Validasi Ahli Materi}

Pada tahap validasi ahli materi pembelajarn untuk bertujuan untuk melihat sejauh mana materi yang ada pada model quantum teaching terhadap media video pembelajaran berbasis camtasia pada materi permukan bumi dan cuaca, mata pelajaran IPA kelas III semester II. Pada tahap ini, dua validator yang dipilih untuk bersedia sebagai validasi ahli materi. Uji validasi terhadap produk dengan memberikan lembar angket validasi ahli materi.

Hasil analisis penilaian ahli materi validasi pada tahap pertama mendapatkan persentase skor total sebesar 55,71\% dengan kriteria Cukup Layak.

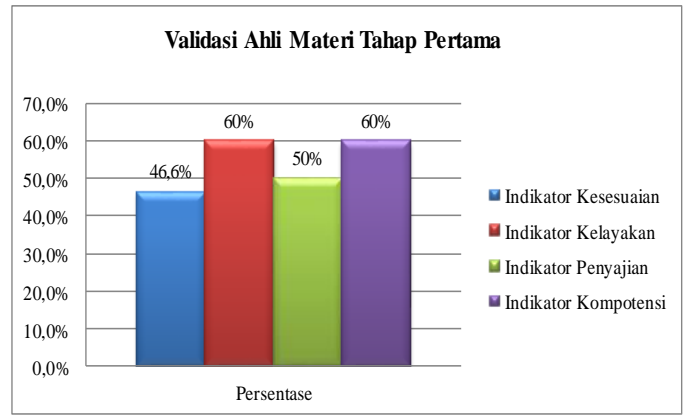

Gambar. 4 Hasil Ahli Materi Tahap Pertama

Pada tahap validator validasi ahli materi tahap pertama mendapatkansaran dan komentar yaitu Rencana Pelaksanaan Pembelajaran (RPP) menyesuiakan model quantum teaching dengan sintaks metode TANDUR, maka dari itu peneliti perlu adanya revisi terhadap produk yang dikembangkan agar sesuai dengan saran dari validator pertama.Setelah selesai melakukan validator pada ahli materi pada tahap pertama, peneliti melakukan validator ahli materi yang kedua

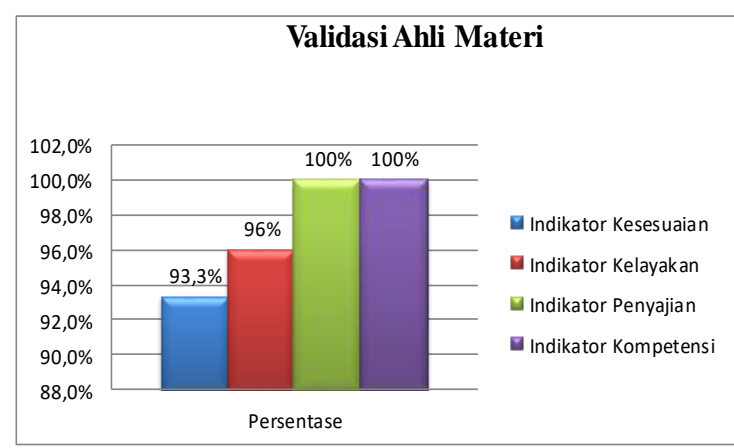

Gambar. 5 Hasil Validator Ahli Materi

Hasil analisis penilaian ahli materi validasi pertama mendapatkan persentase skor total sebesar 95,71 \% dengan kriteria Sangat Layak. Validator ahli materi memberikan saran yaitu produk siap digunakan penelitian atau siap untuk di uji caba lapangan awal. Pada validator yang pertama mendapatkan saran dan komentar untuk revisi produk maka peneliti memperbaiki desain yang sesuai dengan komentar validator ahli materi dan diperoleh hasil analisis penilaian ahli materi validasi materi pada tahap kedua

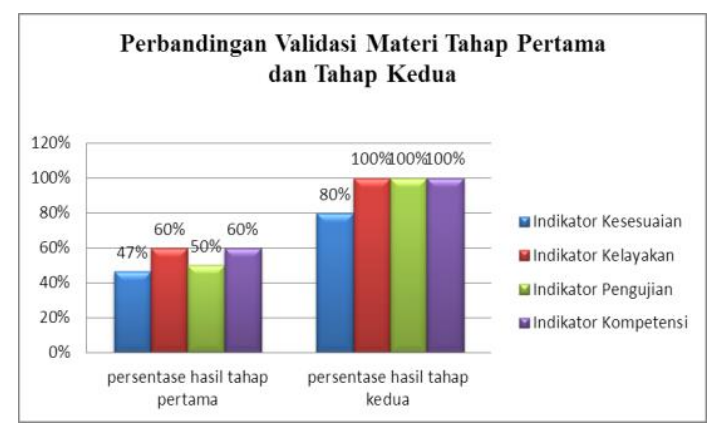

Gambar. 6 Hasil Perbandingan Validasi Materi

Hasil analisis penilaian ahli materi validasi pada tahap kedua mendapatkan persentase 95,71\% dengan kriteria Sangat Layak. Maka dari itu produk yang 
dikembangkan oleh peneliti setelah melakukan validasi dari ahli materi siap untuk di uji coba lapangan awal.

\section{Hasil Angket Respon Guru}

Hasil angeket respon guru kelas III bertujuan untuk mengetahui respon guru kelas III terhadap kelayakan model quantum teaching terhadap video pembelajaran berbasis camtasia pada materi permukaan bumi dan cuaca kelas III semester II. Berdasarkan hasil analisis angket respon guru dalam madia pembelajaran.

Hasil analisis penilaian respon guru dalam media pembelajaran mendapatkan persentase skor total $97,5 \%$ dengan kriteria Sangat Layak.

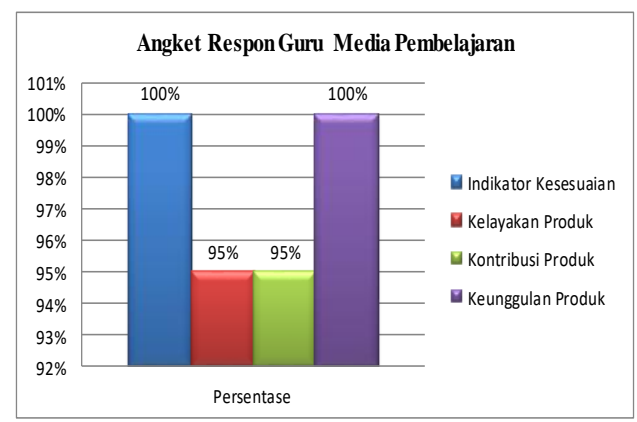

Gambar. 7 Hasil Respon Guru Media

Maka produk yang dikembangkan oleh peneliti mendapatkan kelayakan model quatum teaching terhadap video pembelajaran berbasis camtasia pada materi permukaan bumi dan cuaca kelas III semester II.Selain itu angket respon guru dalam materi pembelajaran memperoleh penilaian.

Hasil analisis penilaian respon guru dalam materi pembelajaran mendapatkan persentase skor total $100 \%$ dengan kriteria Sangat Layak. Maka dari itu produk yang dikembangkan oleh peneliti layak digunakan dalam pembelajaran.

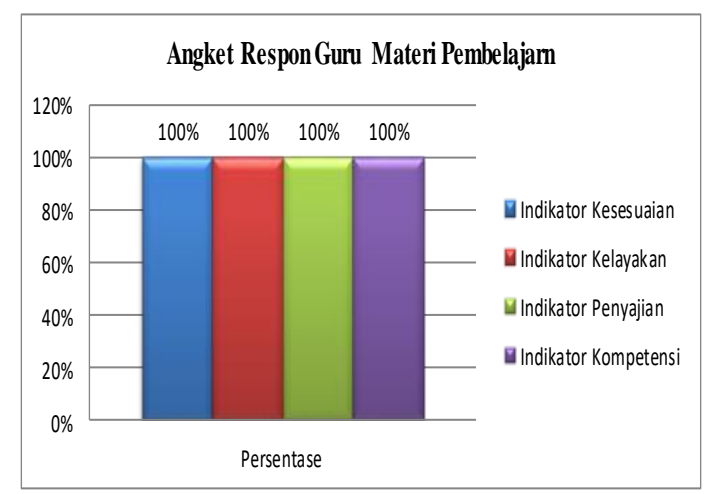

Gambar. 8 Hasil Respon Materi

\section{Hasil Angket Respon Siswa}

Hasil angket respon siswa bertujuan untuk megetahui respon siswa terhadap keberterimaan model quantum teaching terhadap video pembelajaran berbasis camtasia pada materi permukaan bumi dan cuaca dalan mata pelajara IPA kelas III pada uji coba lapangan awal dengan dilakukan pengisian angket respon siswa kelas III di SDN Jomblang 01 Semarang

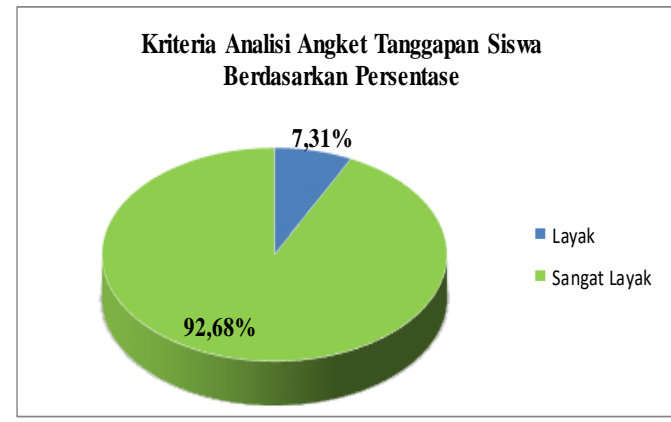

Gambar. 9 Hasil Angket Tanggapan Siswa

Maka dari itu dari hasil angket respon siswa terhadap media video pembelajaran berbasis camtasia terhadap model quantum teaching sangat layak digunakan pada pembelajaran di dalam kelas selain itu siswa 
dapat belajar mandiri menggunakan video pembelajaran yang dikembangkan oleh peneliti dan membantu guru untuk mendapangi pembelajaran terutama mata pelajaran IPA materi permukaan bumi dan cuaca kelas III semester II. Berikut adalah contoh gambar tampilan pengembangan quantum teaching berbasis video pembelajaran camtasia

\section{SIMPULAN}

Berdasarkan hasil penelitian dan pembahasan pada penelitian pengembangan produk model quantum teaching terhadap video pembelajaran berbasiscamtasia pada mata pelajaran IPA materi permukaan bumi dan cuaca kelas III semester II maka dapat disimpulkan bahwa:

1. Dihasilkan produk model quantum teaching terhadap video pembelajaran berbasis camtasia pada mata pelajaran IPA materi permukaan bumi dan cuaca kelas III semester II yang disesuaikan dengan 10 langkah model penelitian dan pengambangan $(R \& D)$ menurut Borg and Gall. Dari sepuluh langkah tersebut peneliti hanya mengambil lima langkah yaitu pada revisi hasil uji coba.

2. Kevalidan model quantum teaching terhadap video pembelajaran berbasis camtasia pada mata pelajaran IPA materi permukaan bumi dan cuaca kelas III semester II dilakukan dengan cara melakukan validasi media pembelajaran dan materi pembelajaran. Penilaian oleh ahli media pada tahap pertama oleh validator pertama dan validator kedua mendapatkan 57,5\% dan $95 \%$ dengan kriteria Cukup Layak dan Sangat Layak. Selain itu pada tahap kedua mendapatkan persentase $95 \%$ dengan kriteria Sangat Layak. Berdasarkan perolehan persentase terhadap validasi ahli materi pada tahap pertama dengan validator pertama dan kedua mendapatkan persentase 95,71\% dan 55,71\% dengan kriteria Sangat Layak dan Cukup Layak. Setelah itu pada tahap kedua persentase 91,25\% dengan kriteria Sangat Layak sehingga video pembelajaran berbasis camtasia pada mata pelajaran IPA valid digunakan uji coba lapangan.

3. Kepraktisan model quantum teaching terhadap video pembelajaran camtasia pada mata pelajaran IPA materi permukaan bumi dan cuaca kelas III semester II dilakukan dengan cara memberikan angket respon guru dan angket tanggapan siswa kelas III SDN Jomblang 01. Hasil tanggapan tersebut diperoleh pada angket respon guru dalam media dan materi $97,5 \%$ dan $100 \%$ dengan kriteria Sangat Layak selain itu hasil dari angket tanggapan siswa 93,75\% dengan kriteria Sangat Layak. Maka dari itu hasil pengembangan model quantum teaching terhadap video pembelajaran berbasis camtasia pada mata pelajaran IPA materi permukaan bumi dan cuaca kelas III semester II praktis digunakan pada kelas III Sekolah Dasar 


\section{DAFTAR PUSTAKA}

Adi, A. P. (2014). Menjadi Pembuatan Film Andal dengan Camtasia Studio 8. Jakarta: PT Elex Media Komputindo.

Arikunto , S. (2010). Prosedur Penelitian Suatu Pendekatan Praktik . jakarta : PT Rineka Cipta.

Arsyad , A. (2015). Media Pembelajaran . Jakarta: Kharisma Putra Utama Offset .

Enterprise, J. (2015). Membuat Video Tutorial Menggunakan Camtasia. Jakarta: PT Elex Media Komputindo.

Kosasih, N., \& Sumarna, D. (2013). Pembelajaran Quantum dan Optimalisasi Kecerdasan . Bandung: Alfabeta, cv.

Permana dkk. 2016. Keefektifan Pembelajaran Quantum Teaching Terhadap Kreatifitas dan Hasil Belajar Matematika Kelas III SDN Peterongan Semarang. Jurnal Profesi Pendidikan Dasar Vol. 3, No. 2, 2016, hlm.154. http://journals.ums.ac.id/index.php/ ppd/article/view/3968/3515

Sanaky, A. H. (2013). Media Pembelajaran Interaktif-Inovatif. Yogyakarta: Kaukuba.

Soegeng, A. (2016). Dasar-Dasar Penelitian. Yogyakarta: Magnum Pustaka Utama.

Sukardi, I. (2013). Model-Model Pembelajaran Modern. Palembang : Tunas Gemilang Press.

Susanto, A. (2016). Teori Pembelajaran \& Pembelajaran di Sekolah Dasar. Jakarta: Prenadamedia Grup HYPERLINK "

Wijayanti , A. (2016). Pengaruh Quantum Teaching Dalam Pembelajaran IPA Terhadap Hasil Belajar Siswa Kelas III SD SE-GUGUS 2 Hasanudin. Jurnal Pendidikan Guru Sekolah Dasar. Edisi 34 Tahun ke 5. http://journal.student.uny.ac.id/ojs/index.php/ pgsd/article/viewFile/5115/4783. 